\title{
A Defense of Analogical Reasoning in Law
}

\author{
Emily Sherwin $\dagger$
}

\begin{abstract}
This Article defends the practice of reasoning by analogy on the basis of its epistemic and institutional advantages. The advantages identified for analogical reasoning include that it produces a wealth of data for decisonmaking; it represents the collaborative effort of a number of judges over time; it tends to correct biases that might lead judges to discount the force of prior decisions; and it exerts a conservative force in law, holding the development of law to a gradual pace. Notably, these advantages do not depend on the rational force of analogical reasoning. Rather, the author contends that, as open-ended reasoning and analogical reasoning alike may sometimes result in incorrect decisions, these qualities of analogical reasoning make it a desirable method of deciding legal disputes.
\end{abstract}

The method by which judges perform their work-that is, the form of reasoning they use in reaching decisions-is a subject of continuing controversy. According to traditional understanding, judges engage in a special form of reasoning, the method of analogy. Closely related to the analogical method of reasoning is the assumption that judges will follow the course suggested by analogy and thus conform their decisions to the existing body of law. My object in this Article is to defend this traditional practice and in doing so to answer some recent objections to analogical reasoning in law.

My argument is based on the epistemic and institutional advantages of the practice of analogical reasoning. Not all proponents of the analogical method will welcome my contribution, because I concede that analogical reasoning is an unscientific practice with imperfect results and then proceed to defend it on conservative grounds. Nevertheless, I believe this is the best way to explain the endurance and success of both the common law and the analogical method that supports it.

\section{ANALOGICAL REASONING}

The analogical method, as commonly practiced, works something like this: confronted with an unsettled question, the judge surveys past decisions, identifies ways in which these decisions are similar to or different from each other and the question before her, and develops a principle that captures the similarities and differences she considers important. ${ }^{1}$ This principle in turn pro-

\footnotetext{
f Professor of Law, University of San Diego School of Law. Thanks to Larry Alexander, Kevin Clermont, Maimon Schwarzschild, and Cass Sunstein for helpful comments.

' See, for example, Edward Levi, An Introduction to Legal Reasoning 1.6 (Chicago
} 
vides the basis for the judge's own decision. ${ }^{2}$ Whatever one may think about the merits of analogical decisionmaking, there is little question that judges writing opinions and lawyers addressing judges often cast their analysis in this form.

In their writings on the legal process, Henry Hart and Albert Sacks refer to this method of judicial decisionmaking as "reasoned elaboration" of law, to be distinguished from an exercise of "discretionary fiat." The virtue of reasoned elaboration, Hart and Sacks suggest, is that it forces courts to decide cases in a manner that is consistent with the expectations of the parties at the time they acted. ${ }^{4}$ When courts build on past decisions, law is predictable even as it evolves to fit new cases.

Another well known description of legal reasoning by analogy comes from Edward Levi. According to Levi, a judge reasoning by analogy studies the facts and outcomes of a case she deems similar to the case before her, formulates the rule "inherent" in the prior case, and then uses it to decide her case. ${ }^{5}$ What Levi sees in this method is a way for law to adapt to the changing circumstances and beliefs of the surrounding community. ${ }^{6}$ Rules of law are "remade with each case."

In Law's Empire, Ronald Dworkin redescribes the traditional method of legal reasoning by analogy as a source of "integrity" in law. ${ }^{8}$ As Dworkin explains it, the task of judges is to construct legal principles that meet a threshold of "fit" with prior decisions and at the same time represent, the "best" possible understanding

1949); Cass R. Sunstein, Legal Reasoning and Political Conflict 62-100 (Oxford 1996); Scott Brewer, Exemplary Reasoning: Semantics, Pragmatics, and the Rational Force of Legal Argument by Analogy, 109 Harv L Rev 925, 925-29, 962-63 (1996). See also Ronald Dworkin, Law's Empire 228-38 (Belknap 1980) (characterizing law as a "chain novel").

${ }^{2}$ My discussion focuses on the development of common law in the absence of a statute, but much the same method can be applied to interpretation of statutes over a period of time. See Dworkin, Law's Empire at 313-54 (cited in note 1) (identifying statutes as part of the "chain of law"); Sunstein, Political Conflict at 83-90 (cited in note 1) (providing examples of analogy in statutory interpretation); Brewer, 109 Harv L Rev at 937-38 (cited in note 1) (offering the ejusdem generis canon of statutory construction as an example of exemplary reasoning).

${ }^{3}$ Henry M. Hart, Jr. and Albert M. Sacks, The Legal Process: Basic Problems in the Making and Application of Law 147-48, 372-77 (Foundation 1994) (William N. Eskridge, Jr. and Philip P. Frickey, eds) (arguing that, in the case of the "burnt bundles," Justice Shaw of the Massachusetts Supreme Judicial Court succeeded in part and failed in part to apply the method of reasoned elaboration to the previously undecided question of a railroad's liability for harm to goods). See Norway Plains Co $v$ Boston \& Maine Railroad, 1 Gray 263, 268 (Mass 1854).

- Hart and Sacks, Legal Process at 398 (cited in note 3).

5 Levi, Legal Reasoning at 1-2 (cited in note 1).

${ }^{6}$ Id at 2-4.

3 Id at 2.

s Dworkin, Law's Empire at 94-96, 225-75 (cited in note 1). 
of those decisions, according to the judge's own moral and political sense. ${ }^{9}$ For Dworkin, the virtue of principles that can be fitted to existing legal materials is that they "secur[e] a kind of equality among citizens that makes their community more genuine and improves its moral justification for exercising the political power it does." 10

More recently, Cass Sunstein has defended analogical reasoning in law as one of several ways in which a society can reach practical agreement against a background of moral controversy. In Sunstein's version of legal reasoning, judges reason from case to case, arriving at low-level reasons why some cases are relevantly similar to others without developing a full theory of decision. ${ }^{11}$ The principal virtue of the method, for Sunstein, is that people who disagree at the level of comprehensive theory may nevertheless be able to agree on low-level analogies among cases. By fixing on modest principles of similarity, courts can settle pressing questions while not taking controversial moral and political positions that are difficult for judges to concur in and for parties to accept. ${ }^{12}$

While the method of analogy is much discussed, its rational force and its position among forms of logic remain somewhat obscure. The most thorough analysis comes from Scott Brewer, who likens analogical reasoning to a Rawlsian process of reflective equilibrium. ${ }^{13}$ As Brewer explains the method of analogy, a reasoner seeking to resolve a problem casts about for examples that, either intuitively or by conventional association, promise to be fruitful sources for comparison with the problem at hand. Then the reasoner "abduces" from these examples a tentative "analogywarranting rule" that posits a logical relation, inductive or deductive, between the examples and the problem. ${ }^{14}$ Next, the reasoner

Id at 254-58.

${ }^{10}$ Id at 96.

"Sunstein, Political Conflict at 65-69 (cited in note 1).

12 Id at 41 ("When the authoritative rationale for the result is disconnected from abstract theories of the good and the right, the losers can submit to legal obligations, even if reluctantly, without being forced to renounce their largest ideals."); id at 91 ("Within the legal culture, analogical reasoning imposes a certain discipline, and a widespread moral or political consensus is therefore unnecessary. Hence, people who could not use analogies to reach closure in politics or morality can often do so in law.").

${ }^{13}$ Brewer, 109 Harv L Rev at 938-39 (cited in note 1) (describing the process of "reflective adjustment" a reasoner must go through when confronted with a particular example that conflicts with a general principle that the reasoner had tentatively accepted); id at 962-63, 1023 (explaining how "reflective adjustment" is used in the course of analogical reasoning to confirm or discard an analogy-warranting rule). On reflective equilibrium as a method of moral reasoning, see John Rawls, $A$ Theory of Justice 46-53 (Belknap 1971).

"Brewer, 109 Harv L Rev at 962 (cited in note 1). 
confirms the rule by testing it "up" against possible "analogywarranting rationales" and "down" against further examples. ${ }^{15}$ If the analogy-warranting rule survives this process, it becomes likely that what is true for the examples is also true for the problem case. ${ }^{16}$ Thus, in Brewer's view, the method of analogy has at least some rational force, although its conclusions are neither inductively demonstrated nor deductively proven. ${ }^{17}$

Suppose, for example, that a court faces a case in which the defendant, a contractor, found buried money under the plaintiff's garage. ${ }^{18}$ The court surveys past cases having to do with things lost and found and finds the following:

(1) several cases in which someone found money on the floor of a shop or similar premises and the courts held that the finder was entitled to retain possession as long as the owner of the lost property was not known; ${ }^{19}$

(2) several cases in which someone found money on a table in a shop or on a chair in a bank safe deposit room and the courts held that the owner of the place where the money was found was entitled to possession; ${ }^{20}$ and

${ }^{15}$ Id at 1022-23.

${ }^{16}$ Id at 1022 ("By supplying criteria of acceptability, the [analogy-warranting rationale] plays the vital role in exemplary reasoning of guiding the reasoner toward judgements of truth.").

${ }^{17}$ Id at 954-55 ("Skeptics ... . are right to think that analogical argument does not have the same degree of rational force as induction or deduction. But they perhaps overlook the significant constraints on analogical arguments by failing to see that .... induction (in some contexts) and deduction (in other contexts) actually plays a vital role in analogical argument."). Howard Margolis has taken the interesting position that all human reasoning is "patterned" or analogical in nature. See Howard Margolis, Patterns, Thinking, and Cognition: A Theory of Judgment (Chicago 1987). Margolis argues that we analyze new situations by searching for "cues" that trigger patterns familiar from previous experience. This process of association allows us to reach an initial conclusion about the new situation, which can then be refined by comparison with other known patterns. The method of reasoning Margolis describes is path dependent and therefore necessarily imperfect. Yet it is the means by which our minds progress from one point to another.

18 This is taken loosely from the facts of Schley $v$ Couch, 284 SW2d 333 (Tex 1955) (holding buried property to belong to the owner of the premises on which it was found because it is more appropriately considered mislaid than lost property).

${ }^{19}$ See, for example, Bridges $v$ Hawkesworth, 21 L J Q B 75 (1851) (holding that finder has title to a bundle of notes found on a shop floor against all but the true owner).

${ }^{20}$ See, for example, McAvoy $v$ Medina, 11 Allen 548 (Mass 1866) (holding pocketbook left on a table in a shop to be mislaid property and thus granting ownership of the pocketbook to the owner of the shop against the finder); Pyle $v$ Springfield Marine Bank, 330 Ill App 1, 70 NE2d 257 (1946) (holding that a bank has right of possession against a finder of a treasury note found on the floor of the bank's vault room because the vault room was a private place). 
(3) a case in which someone found a brooch on a window ledge in a house temporarily requisitioned by the government and the court held that the finder was entitled to possession. ${ }^{21}$

The court might then propose the following analogywarranting rule: when property is found in circumstances that suggest its owner set it down deliberately and then forgot it, the right to possession should go to the owner of the place where the property was found. If, however, it seems that the owner dropped the property inadvertently, possession should go to the finder. This rule leaves one possibly recalcitrant case (the case of the brooch), but the rule appears to be justified by a broader analogywarranting rationale-that owners who have set property down and then forgotten it are more likely to return to the site than those who have dropped their property inadvertently. The more likely the owner is to return, the less appealing it is to award the property to finders who are comparatively more difficult for the owner of the lost property to trace. These ideas in turn can be tested at higher levels of generality: a rule designed to return lost property to its owner will make property rights more secure, secure property rights contribute to general prosperity, and so forth. The analogy-warranting rule can also be tested against hypothetical future cases to see if it produces satisfying outcomes. If the results of testing are acceptable, and if we assume that the prior decisions were correct, we may now have some reason to believe that the money found under the garage should stay with the owners of the house.

\section{OBJECTIONS TO THE ANALOGICAL METHOD}

Analogical reasoning as a method of resolving legal disputes is not universally admired. Legal realists viewed analogical reasoning as infinitely malleable and therefore scorned the notion that it could restrain judges from doing as they pleased. ${ }^{22}$ More recently, the validity of analogical reasoning has been questioned by rationalists who find it logically flawed and possibly incoherent. $^{23}$

${ }^{2 !}$ Hannah v Peel, 1 KB 509 (1945).

${ }^{2}$ See, for example, Karl N. Llewellyn, The Bramble Bush 66.69 (Oceana 1969) (contending that judges use a strict view of precedent to get rid of "troublesome" precedents and a weak view of precedent to keep "helpful" precedents).

${ }^{23}$ See, for example, Richard A. Posner, The Problems of Jurisprudence 86-98 (Harvard 1990) (arguing that analogical reasoning "denotes an unstable class of disparate reasoning methods," some harmful); Frederick Schauer, Playing by the Rules: A Philosophical Examination of Rule-Based Decision-Making in Law and in Life 183-87, esp 187 (Oxford 1995) (describing analogical reasoning as a form of deduction from rules); Larry Alexander, Bad Beginnings, $145 \mathrm{U}$ Pa L Rev 57, 80-86 (1996) (arguing that analogical reasoning 
Frederick Schauer, for example, suggests that analogical reasoning is either a form of deduction from rules, or nothing at all. ${ }^{24}$ If the prior decision is no more than a result reached on a given set of facts, the present judge must construct a generalization that encompasses both the prior case and the case before her, and it is this generalization that drives the judge's decision..$^{25}$ If, instead, the necessary generalization is contained in the prior decision, either expressly or by implication from natural or culturally determined categories, the present judge is simply applying a rule. ${ }^{26}$ There is no special analogical form of reasoning involved.

Richard Posner is similarly skeptical about analogy as a form of reasoning. Posner suggests that what passes as analogical reasoning in law is sometimes a perilous form of induction (perilous because of its normative element), sometimes a practice of deduction from rules that have not been fully justified, sometimes a reference to prior cases as nonauthoritative sources of information, and sometimes a rhetorical device that obscures the grounds of decision. ${ }^{27}$ The analogical method may be useful as a test of existing legal rules, and it may add stability to law, but in Posner's view judges would do better by engaging in straightforward analysis of the relative importance of stability and correct decisionmaking. ${ }^{28}$

The most pointed and comprehensive recent criticism of the method of analogy comes from Larry Alexander. ${ }^{29}$ Like Schauer and Posner, Alexander questions whether analogical reasoning in law is a distinct form of reasoning, but his main focus is on the inferiority of analogical decisionmaking to ordinary moral reasoning. Analogical reasoning, unlike reflective equilibrium, starts with the prior decisions of others rather than the reasoner's own observations and intuitions. Because judges are fallible, some of

in law is flawed because it relies on legal principles from past decisions even though many past decisions must be morally mistaken).

${ }^{21}$ Schauer, Playing by the Rules at 182-87 (cited in note 23).

25 Id at 184.

${ }^{25}$ Id at 187 ("E]xcept for the fact that the lack of a canonical formulation of a factual predicate substantially increases the indeterminacy of the rule set forth in the precedent case ... , nothing about a precedent-based constraint uniquely differentiates it from rulebased constraint.").

${ }^{27}$ Posner, Problems of Jurisprudence at $86-98$ (cited in note 23).

${ }_{28}$ Id at $90-91$.

- Alexander, $145 \mathrm{U} \mathrm{Pa} \mathrm{L}$ Rev at 80-86 (cited in note 23). See also Larry Alexander, Incomplete Theorizing: A Review Essay of Cass $R$. Sunstein's Legal Reasoning and Political Conflict, 72 Notre Dame L Rev 531, 535-41 (1997) (criticizing Sunstein's arguments for analogical reasoning); Larry Alexander and Ken Kress, Against Legal Principles, in Andrei Marmor, ed, Law and Interpretation 279 (Clarendon 1995) (criticizing Dworkin's "legal principles"); Larry Alexander, Constrained By Precedent, 63 S Cal L Rev 3, 28-48 (1989) (criticizing "result models" of precedent). 
these prior decisions are sure to be wrong. Thus, the basic data are flawed and decisionmaking by analogy will simply entrench the errors of the past. ${ }^{30}$

To be sure, a judge's moral reasoning also may be flawed, but, Alexander argues, it at least represents the judge's best efforts to avoid error. In contrast, analogical reasoning-to the extent it diverges from the judge's own moral judgment-works deliberately from a set of decisions that the judge believes are not all correct in fact. As Alexander puts it, analogical reasoning asks the question, "What would be the morally correct outcomes, in a world in which some morally incorrect outcomes in our world were morally correct?" ${ }^{31}$ In Alexander's view, not only must the answer to such a question be normatively unattractive, but the question itself is nonsense.

Having dismissed the method of analogy, Alexander maintains that the only legitimate forms of legal reasoning are straightforward moral reasoning-determining what is best, all things considered-and deduction from authoritative rules. ${ }^{32}$ The outcomes of past cases are important only insofar as people have relied on them, and reliance is a consideration that can be fully accounted for in the course of ordinary moral reasoning. ${ }^{33}$ Alexander allows that, for reasons of guidance, predictability, and coordination, judges should sometimes announce rules in canonical form, and that future judges should treat these rules as binding. ${ }^{34}$ A rule of precedent requiring judges to follow rules announced in past cases, even when they believe the rules are wrong, prevents judges from underestimating reliance or undervaluing other ruleof-law virtues. ${ }^{35}$ But, in the absence of a rule, judges should exercise their moral judgment to the best of their abilities rather than incorporate the mistakes of the past.

\footnotetext{
${ }^{3}$ Alexander, $145 \mathrm{U} \mathrm{Pa} \mathrm{L}$ Rev at 80-87 (cited in note 23). Of course, the problem of entrenched error is present when judges apply the principle of stare decisis in any form, including adherence to canonical rules announced in past cases. In Alexander's view, however, analogical decisionmaking carries the cost of entrenched error without the benefits of guidance and stability associated with canonical rules. Id at 81-82.

"s Id at 86-87 $\mathrm{n} 96$.

${ }^{32}$ Id at 70-71.

${ }^{33}$ Id at 81 ("Ordinary moral reasoning will take account of all the present effects of past decisions, including morally erroneous ones. Because we operate morally in the world as we find it-a world in which many of its features are the residue of past mistakes-we must take account of those mistakes in order to act morally.").

" A rule is "canonical" when it has been given a particular authoritative formulation. On canonicity, see Schauer, Playing by the Rules at 68-72 (cited in note 23).

${ }^{35}$ Alexander, $63 \mathrm{~S}$ Cal L Rev at $48-51$ (cited in note 29 ).
} 


\section{A DEFENSE OF THE ANALOGICAL METHOD}

While I accept much of what these critics say about analogical reasoning in law, I believe they have overlooked some of its potential virtues and have not considered it in its most attractive form. My own defense of analogical reasoning follows a somewhat different route than others have taken. I disagree with Levi's suggestion that analogy is a promising vehicle for legal change. I doubt whether equality (what Dworkin calls "integrity") can justify a judge in reaching a decision she believes is wrong; therefore, equality does not play a part in my argument. ${ }^{36} \mathrm{I}$ think there may be something to Sunstein's argument that analogy can serve as a means of "incompletely theorized" agreement, but this is not the approach I will take. I agree with Hart and Sacks that a process of elaboration from past cases adds to the predictability of law, and I will incorporate their argument as part of my own. But I do not think this is all that can be said on behalf of analogical reasoning.

In my view, the virtue of analogical reasoning lies in a variety of indirect benefits that are likely to result when judges adopt it as a practice and consider themselves obliged to explain new decisions in terms of their relation to past cases. First, a diligent process of studying and comparing prior decisions produces a wealth of data for decisionmaking. Second, the rules and principles that result from analogical reasoning represent the collaborative efforts of a number of judges over time. Third, analogical reasoning tends to correct biases that might otherwise lead judges to discount the likelihood or importance of reliance on prior decisions. Fourth, analogical reasoning exerts a conservative force on law: by holding the development of law to a gradual pace, it limits the scope of error and contributes to public acceptance of law as a standard of conduct.

As I have suggested, these advantages are indirect. They are not attributable to the rational force of the analogical method, and they are consistent with the claim that the results of analogical reasoning will sometimes be wrong. Open-ended moral reasoning, however, is also subject to error. If I am right about these indirect benefits, analogical reasoning may result in better decisions and rules overall.

The case for analogical reasoning in law begins with certain background assumptions about the circumstances of judges. Assume that the judge in question is an appellate judge deciding

${ }^{36}$ See Alexander, $145 \mathrm{U} \mathrm{Pa} \mathrm{L} \mathrm{Rev} \mathrm{at} \mathrm{85-86} \mathrm{(cited} \mathrm{in} \mathrm{note} \mathrm{23);} \mathrm{Alexander} \mathrm{and} \mathrm{Kress,}$ Against Legal Principles at 294-95 (cited in note 29). 
how to vote and how to draft an opinion. This judge faces a single case based on specific events in the lives of individuals, which are described in the record of the case. She has limited time to spend on the case and has no option but to decide in favor of one party or another. The facts before her are simplified both by the rules of evidence at trial and by the manner in which the trial has been reported. She is expected to articulate reasons for her decision that operate at some intermediate level of generality. Parties, critics, and other judges will be disappointed if she decides either "because the facts are thus" or "because I believe this is best." Finally, the judge is fallible - she makes factual, logical, and moral mistakes.

\section{A. Exposure to Examples}

In these circumstances, one simple advantage of the analogical method of decisionmaking is that past cases provide the judge with a ready supply of examples from which to develop reasons for decision. Tentative reasons for decision may be suggested by the explanations that prior judges have given for their decisions, or reasons may surface intuitively as the judge looks for similarities and differences among the cases. Once the judge has arrived at tentative reasons for her own decision, she can check and refine them by examining how they might apply to the facts of, or facts suggested by, past cases. She might invent hypothetical cases for this purpose, but these are likely to be overly simple in comparison to actual, decided cases. It is true that reported cases will contain only a limited set of facts, selected by the same fallible judge who decided the case.$^{37}$ Nevertheless, past cases resolving real disputes are likely to be more realistic and more detailed than examples the present judge might conceive in the short time she has to make a decision.

The critic of analogical reasoning might respond that of course it is useful for the judge to survey past decisions in the process of deliberation, but there is no justification for accepting cases the judge believes were wrongly decided as fixed starting points for her own decision. ${ }^{38}$ The judge should study past cases, but if she believes they are wrong, she should not endeavor to make her decision consistent with them. Building from them

\footnotetext{
${ }^{37}$ See Alexander, $63 \mathrm{~S} \mathrm{Cal} \mathrm{L} \mathrm{Rev} \mathrm{at} 42-44$ (cited in note 29) (arguing that facts are screened through rationales).

36 See Posner, Problems of Jurisprudence at 89-92 (cited in note 23) (discussing the use of past decisions as nonauthoritative sources of data about past experience).
} 
simply ensures that her own decision will be less accurate than it otherwise might be.

If we could count on judges to engage in a meticulous study of past cases in the process of reaching independent decisions, this criticism might be persuasive. But when cases must be decided quickly, a judge cut free from the obligation to reconcile her own decision with past decisions will often find it easiest to apply her own judgment, perhaps tested against a few rapidly composed hypotheticals. If, in contrast, she feels obliged to seek analogies, she has reason to sift more carefully through reported opinions. In other words, the practice of analogical reasoning from past decisions has procedural benefits that go beyond the rational force it carries in any particular case. It produces a habit, a method, that will lead judges to do the intellectual work of study and comparison.

This point applies with particular force when judges design general rules of common law for future application. Like Alexander and Schauer, I take it to be desirable and possibly inevitable that judges should announce general rules from time to time. Casting a decision in general terms, as a rule for future cases, has important advantages for guidance and coordination. ${ }^{39}$

The difficulty with this position is that adjudication is not an ideal setting for fashioning rules of general application. A judge focuses her attention primarily on the facts before her, facts presented by the parties to a single dispute. Others who might be affected by a general rule announced by the judge are not represented in the proceeding and will be remote in the mind of the judge. In these circumstances, the process of reviewing and sorting cases in the course of analogical reasoning will give the judge a better sense of the field of possibilities to which her rule might apply. And once again, judges are more likely to undertake a review of past cases if they feel obliged to do so in the course of reaching a decision.

Past decisions are not the only sources of ideas that a judge might usefully study. Alexander suggests, for example, that a judge might find the moral judgments of the Harvard Philosophy

${ }^{39}$ See Alexander, $63 \mathrm{~S} \mathrm{Cal} \mathrm{L} \mathrm{Rev} \mathrm{at} \mathrm{48-51} \mathrm{(cited} \mathrm{in} \mathrm{note} \mathrm{29)} \mathrm{(explaining} \mathrm{the} \mathrm{need} \mathrm{for}$ judicial rules). On rules generally, see Joseph Raz, The Morality of Freedom $42-57$ (Clarendon 1986) (discussing the "normal justification" of authoritative rules and the relationship of justified rules to the ends of rule-subjects); Schauer, Playing by the Rules at 3566 (cited in note 23) (outlining reasons for authoritative rules); Larry Alexander and Emily Sherwin, Past Imperfect: Rules, Principles, and Dilemmas of Law ch 5 (unpublished manuscript on file with $U$ Chi L Rev) (discussing the need for authoritative rules and the problems such rules cause). 
Department more helpful than the judgments of past courts. ${ }^{40}$ Yet it is all too easy to overlook the potential consequences of a comprehensive moral theory when applying it to just one case. The method of analogy minimizes this danger by drawing the judge's attention to an array of concrete situations and placing the judge in the posture of reflective equilibrium.

\section{B. Collaboration}

Moving to the second advantage of analogical reasoning, there is reason to think that, at least in some circumstances, past decisions will yield sound insights. Suppose, for example, that the judge discovers a group of cases that she considers similar to the case before her. These cases were decided over a period of time, but none of them is seriously outdated. Newer cases refer with approval to older cases in the group. None of the cases states a canonical rule governing the present case, but if taken together they imply a principle-an analogy-warranting rule-that would also provide an answer to the present case.

The judge may not be persuaded that the principle implied by the line of past cases is the best ground on which to decide, and she may think some cases in the line were wrongly decided. Nevertheless, if the pattern of the decisions and the remarks of the judges who decided them suggest a common idea, that idea is worth attending to because it represents the collective reasoning of a number of judges over time. Because judges are fallible, the idea running through the cases may be mistaken. But the reasoning of the present judge also may be mistaken. Other things being equal, the epistemic advantage lies with an idea or principle that has been developed and accepted collectively over time.

The type of collective effort brought about by the analogical method is particularly important in the development of judicial rules. For the reasons given earlier, a single judge is not particularly well situated to formulate rules to govern a range of future cases. When judges work by analogy and give precedential weight to the results of analogical reasoning, they can develop rules gradually and postpone stating them in canonical form until the rules have passed through a number of hands and proved effective in a variety of settings.

The suggestion that principles developed over time have epistemic value is not new, of course. Lord Coke, for one, said that "if all the reason that is dispersed into so many severall

${ }^{+0}$ Alexander, $145 \mathrm{U} \mathrm{Pa} \mathrm{L}$ Rev at 74 (cited in note 23). See also Posner, Problems of Jurisprudence at 94-95 (cited in note 23) (discussing alternative sources for judicial decision). 
heads, were united into one, yet could he not make such a law as the law in England is; because by many successions of ages it hath beene fined and refined by an infinite number of grave and learned men, and by long experience growne to such a perfection. ..."11 Edmund Burke warned that one great danger of revolution was its effect on "the science of jurisprudence, the pride of the human intellect, which, with all its defects, redundancies, and errors is the collected reason of the ages, combining the principles of original justice with the infinite variety of human concerns." ${ }^{\text {"42 }}$

Critics might reply that the epistemic value of a pattern of decisions is merely something that present judges should take into account in their own reasoning. They should give the fact of collective acceptance over time the respect they think it deserves, but no more. Yet once a judge has reached an independent conclusion about how a case should be decided, it will be psychologically difficult for her to assign significant epistemic value to contrary suggestions. ${ }^{43}$ If, on the other hand, judges assume from the outset that it is part of their task to conform to the body of past decisions, they are more likely to give real weight to those decisions.

\section{Correction of Bias}

More specifically, analogical reasoning also can counteract the errors of open-ended judgment by building in protection for reliance. Few would deny that, if people have relied on prior judicial decisions, this is a morally important fact that should play a part in a judge's reasoning. Reliance creates a reason for the judge to conform her own decisions to past decisions, even when

"Sir Edward Coke, The First Part of the Institutes of the Laws of England $\S 138$ (Small 1853) (Francis Hargrave and Charles Butler, eds). This passage is quoted by Dean Pound, though he was not an unqualified believer in reasoning by analogy. Analogies, in Pound's view, are helpful only if tested "in the light of how they meet or fail to meet the exigencies of reasonable expectations of men in the time and place." Roscoe Pound, Law Finding Through Experience and Reason 47 (Georgia 1960).

${ }^{12}$ Edmund Burke, Reflections on the Revolution in France, and on the Proceedings in Certain Societies in London Relative to that Event (1790), reprinted in Edmund Burke, Selected Writings and Speeches 424, 469-70 (Regnery Gateway 1963) (Peter J. Stanlis, ed). See Robert C. Clark, Contracts, Elites, and Traditions in the Making of Corporate Law, 89 Colum L Rev 1703, 1730-37 (1989) (discussing the pros and cons of tradition as a source of rules); Isaac Erlich and Richard A. Posner, An Economic Analysis of Legal Rulemaking, 3 $\mathrm{J}$ Legal Stud 257, 266-67 (1974) (discussing some of the benefits of decisionmaking according to rules).

${ }^{4}$ See Stuart Oskamp, Overconfidence in Case-Study Judgments, in Daniel Kahneman, Paul Slovic and Amos Tversky, eds, Judgement Under Uncertainty 287, 290-92 (Cambridge 1982) (showing that confidence, but not accuracy, increases as information increases). 
she believes the past decisions were wrong. This is the point made by Hart and Sacks in defense of analogical reasoning from past decisions. ${ }^{44}$ Critics might respond that while reliance is certainly of moral concern, it is simply a fact that the judge should take into account in deciding what to do, all things considered. ${ }^{45}$ Reliance on past decisions should be given exactly the moral weight it deserves, and no more.

This response to the problem of reliance is unsatisfactory because judges engaged in open-ended reasoning are particularly likely to err in calculating the importance of reliance on past decisions. One of the cognitive biases that affects human reasoning favors information that is salient or "available"-information that comes readily to mind. We focus quickly on information of this kind, at the expense of more remote or abstract considerations that also bear on accurate calculation. ${ }^{46}$ To give just one example from the studies, people commonly underestimate the time necessary to complete a project. The best explanation for this error is that they concentrate their attention on the steps they themselves will need to perform and, as a result, fail to consider the probability that external events may cause a delay. The actor's own tasks are salient, while background risks are relatively obscure. ${ }^{47}$

The circumstances of adjudication make it likely that the judge will undervalue reliance as a reason to conform to past decisions. The salient facts are the identity of the parties before the court and the events that led to a dispute between them. The fact that the parties' own actions were affected by past judicial decisions may catch the judge's attention. But the judge is not likely to focus with the same clarity on reliance by parties who are seldom identified and are not before the court. The hardship of a particular defendant in a contract dispute, for example, may loom larger than the confusion that a novel type of defense might cre-

" See generally Hart and Sacks, The Legal Process at 143-45 (cited in note 3).

* Alexander, 63 S Cal L Rev at 13-14 (cited in note 29). See also Alexander, $145 \mathrm{U} \mathrm{Pa}$ $\mathrm{L}$ Rev at 70, 81-82 (cited in note 23) (characterizing reliance as an ingredient of moral reasoning and past decisions as no more than relevant facts about the world).

${ }^{45}$ See Amos Tversky and Daniel Kahneman, Availability: A Heuristic for Judging Frequence and Probability, in Kahneman, Slovic and Tversky, eds, Judgment Under Uncertainty 163, 163-65, 174-78 (cited in note 43) (explaining the availability bias). Judicial reasoning about reliance is also likely to be affected by the hindsight bias, in which outcomes eclipse antecedent probabilities. See Jeffrey J. Rachlinski, A Positive Psychological Theory of Judging in Hindsight, $65 \mathrm{U}$ Chi L Rev 571, 571-75, 602-24 (1998) (discussing "hindsight bias" and the legal mechanisms developed in response).

${ }^{17}$ Daniel Kahneman and Amos Tversky, Intuitive Prediction: Biases and Corrective Procedures, in Kahneman, Slovic and Tversky, eds, Judgment Under Uncertainty 414, 415-16 (cited in note 43). 
ate in the commercial world..$^{48}$ The practice of analogical reasoning, in which judges take past decisions as more or less fixed starting points for analysis, tends to counteract this bias.

Alexander makes an alternative proposal for counteracting judicial error in assessment of reliance: that judges should adopt a rule of precedent that requires them to follow rules announced in past cases. ${ }^{49}$ If judges are prone to underestimate reliance, then in the long run they will make fewer errors by following the rule than by deciding as they think best, all things considered. Beyond the special situation of announced rules, however, judges should simply treat reliance as a fact to be considered in the course of open-ended reasoning. ${ }^{50}$

This response puts too much weight on the distinction between canonical rules and noncanonical implications of past decisions. First, this distinction is very difficult to make. ${ }^{51}$ Moreover, Alexander's proposal does not fully protect those who rely on judicial decisions. At least as our legal culture has evolved, reliance on judicial decisions is not limited to canonical rules. Lawyers commonly study the facts and outcomes of past decisions, as well as vague judicial remarks that do not qualify as canonical holdings, in an effort to assess what is likely to happen in cases that appear similar but are not covered by the holdings themselves. If delivery wagons have been classified as common carriers and held strictly liable for losses to goods during transit, a railroad may be able to anticipate that it too will be held strictly liable, even if the category of common carriers has not yet been given a canonical form that includes railroads. ${ }^{52}$

Analogy, in other words, is not only a judicial practice but an accepted tool of legal planning. While parties may be more likely to act in reliance on canonical rules than on the implications of a pattern of decisions, the difference is only one of degree. And if I am right that actors and lawyers behave in this way, then analogical reasoning on the part of judges may serve indirectly to protect their expectations.

${ }^{4}$ See generally Campbell Soup Co $v$ Wentz, 172 F2d 80, 83-84 (3d Cir 1948) (holding plaintiff's contract to purchase carrots from defendant was unenforceable in equity because the "sum total of its provisions drives too hard a bargain for a court of conscience to assist").

19 Alexander, $145 \mathrm{U} \mathrm{Pa} \mathrm{L} \mathrm{Rev} \mathrm{at} 70$ (cited in note 23); Alexander, $63 \mathrm{~S} \mathrm{Cal} \mathrm{L} \mathrm{Rev} \mathrm{at} \mathrm{48-}$ 51 (cited in note 29).

so Alexander, $145 \mathrm{U} \mathrm{Pa} \mathrm{L} \mathrm{Rev} \mathrm{at} 70$ (cited in note 23).

${ }^{5 t}$ See Llewellyn, Bramble Bush at $41-52$ (cited in note 22) (giving examples of the difficulty of distinguishing among facts, holdings, rationales, and dicta).

${ }^{52}$ See generally Norway Plains $v$ Boston \& Maine Railroad, 1 Gray 263 (Mass 1854) (holding a railroad liable as common carrier during transit). 
It might be said that the argument I have just made has a circular quality: were it not for the common practice of analogical reasoning by judges-a practice critics view as undesirable-actors and their lawyers would not rely on noncanonical implications of past cases in the manner I describe. Yet reliance of this kind may be something we want to encourage. People can act more confidently if there is some basis for predicting not only what will happen in cases covered by canonical rules but also what direction the law is likely to take.

\section{Evolutionary Decisionmaking}

My argument so far has been that the practice of analogical reasoning by judges may produce fewer errors than a straightforward analysis of what is best, for reasons that are independent of the actual rational force of analogy. Analogical reasoning forces judges to the task of reflective equilibrium, which is likely to improve the overall quality of judicial reasoning and rulemaking, even if some of the reference points for reflection are wrong. Analogical reasoning incorporates the insights of many judges over time. It also works indirectly to protect against insufficient judicial attention to reliance on past decisions. For these reasons, while analogical reasoning will build some errors into the law, it may nevertheless produce better decisions than judges would reach if they followed their best unguided judgment.

Analogical reasoning has another set of benefits, which are not epistemic but institutional. These benefits arise from the role that the method of analogy plays in preserving the evolutionary character of the common law. When judges reason from and attempt to conform to a body of existing decisions, their own decisions and the rules they announce are likely to be modest. Accordingly, law will develop and change in an incremental manner. There are notorious exceptions, such as the constitutional "right to privacy" developed by the Supreme Court ${ }^{53}$ and the "implied warranty of habitability" grafted onto landlord-tenant law by Judge Skelly Wright.. ${ }^{54}$ But in general the method of analogy is not conducive to wide-ranging conclusions: small innovations and modest rules are easier to reconcile with past decisions than large

${ }^{53}$ See Griswold $v$ Connecticut, 381 US 479 (1965) (finding evidence of a right to privacy in cases interpreting the Bill of Rights).

${ }^{54}$ Javins $v$ First National Realty Corp, 428 F2d 1071, 1077-80 (DC Cir 1970) (finding "implied warranty of habitability" where tenants refused to pay rent after alleging that landlord had violated approximately 1,500 of the Housing Regulations of the District of Columbia). 
new ideas. Overall, therefore, analogical reasoning favors an incremental, evolutionary rate of legal development and change.

One reason why it might be desirable for judges to proceed at a slow pace is that the damage any one mistaken judge can cause is limited. There will be errors, and once made, these errors will enter into the body of law to which future judges are expected to refer. But because judges are unlikely to announce sweeping rules, their mistakes will seldom be catastrophes. Lines of decision may sometimes evolve into dead ends, but when this becomes evident the line can be overruled by statute or, in obvious cases, by a court. The ability to trace the development of a doctrine over time may in fact make it easier to see whether and why that doctrine is a mistake.

More important than this, however, is the relationship between evolutionary decisionmaking and public acceptance of law. No system of law can be satisfactory if it relies exclusively on sanctions to secure obedience to its rules. It will fare much better if most of those who are subject to law look on legal rules as proper standards for their own and others' conduct. ${ }^{55}$ And the public is most likely to take this view if law remains within the range of prevailing values and expectations. If law is too disruptive of accepted beliefs or patterns of life, or too unfamiliar in its demands, it will be viewed by its subjects as a set of alien commands.

On the legislative side, accountability to a majority of voters and the inertia of political processes may prevent legislation from moving too far out of line with the society it governs. Judges, in contrast, are limited primarily by the conservative tendencies of analogical reasoning. As long as judges take it as their task to reach decisions and fashion rules that can be reconciled with previous decisions, the law is unlikely to find itself far in advance of public expectations. ${ }^{56}$

${ }^{*}$ See H.L.A. Hart, The Concept of Law 56-57, 88-91 (Clarendon 2d ed 1994) (discussing the "internal aspect" of rules). The importance of this attitude stems from the nature of rules. General rules seldom if ever dictate the right result in all the cases they govern. It may nevertheless be desirable that people follow rules without exception if they are likely to err in their assessment of exactly when it would be better to violate the rule. At the same time, it is not rational for an individual to follow a rule when she believes, upon reflection, that she ought to break the rule. From a systemic perspective, therefore, it is desirable that the subjects of rules form the habit of following legal rules without much reflection. See Schauer, Playing by the Rules at 128-34 (cited in note 23) (describing the "asymmetry of authority"); Alexander and Sherwin, Past Imperfect ch 5 (cited in note 39) (describing the functions of rules, the irrationality of following rules, and the dilemmas rules pose for a legal system).

${ }^{36}$ Another institutional benefit of the analogical method results not from the evolutionary pace of decisionmaking but from the belief that judges are constrained by princi- 


\section{E. Analogical Reasoning Revisited}

What I have said about the epistemic and institutional benefits of analogical reasoning also affects the form that analogical reasoning should take and, in particular, what should qualify as the basic data for analogy. Alexander assumes that judges engaged in analogical reasoning work strictly from the outcomes of prior cases-what results were reached on stated facts. The rationales and remarks that judges have offered in their opinions, and possibly even the rules they have laid down in canonical form, are disregarded in the process of constructing a principle (or analogy-warranting rule) to govern the case at hand. ${ }^{57}$ Alexander also appears to assume that every previously decided case (or every case within the appropriate jurisdiction) is equally authoritative as a source of analogy. ${ }^{58}$

If the process of analogy were simply one of inventing a principle that could explain both past and present outcomes, the result would indeed be unnecessary error with little or no compensating benefit. And some of the literature on analogical reasoning appears to take just this view. Levi insisted that judges should reason from past results rather than rules or rationales, because he viewed the process of analogical reasoning as a means by which creative judges could escape the implications of deductive reasoning and move the law forward to reflect changing circumstances and ideas. ${ }^{59}$ Dworkin was not much interested in the rationales of past decisions, because he sought to combine "integ-

ples or patterns of decisions that are not entirely of their own making. This advantage is not specific to analogical reasoning: it attaches to stare decisis in any form and probably is strongest when judges follow canonical rules announced in prior cases. In the absence of controlling rules, however, the analogical method adds at least some appearance of constraint. It can be argued that the actual constraint provided by analogical reasoning is minimal, because judges themselves must generate the analogy-warranting rules that govern their decisions and have considerable leeway in choosing among rules. See, for example, Schauer, Playing by the Rules at 184 (cited in note 23); Posner, Problems of Jurisprudence at 95-96 (cited in note 23). Yet the field of eligible rules is limited by natural and conventional categories. Schauer, Playing by the Rules at 186. Moreover, whatever its actual effects, analogical reasoning creates the impression that judges are guided by something other than their own, possibly idiosyncratic, beliefs. This in turn allows the public to view law as stable and impartial.

${ }^{57}$ Alexander, $145 \mathrm{U} \mathrm{Pa}$ L Rev at 59 (cited in note 23) (describing Sunstein's account of analogical reasoning); id at 72-73 (suggesting that rationales must be excluded to prevent analogy from collapsing into deduction).

${ }^{\text {ss }}$ See id at 74 (describing past judgments as "fixed points" of reference that cannot be disregarded or revised).

${ }^{50}$ See Levi, Legal Reasoning at 2 (cited in note 1) (contending that judges are not bound by prior judges' statements). 
rity" with a high level of theoretical endeavor by the individual judge ("Hercules"). ${ }^{60}$

The reasons I have put forward in favor of analogical reasoning, however, support a different understanding of the practice. If judges are truly attempting to build from, rather than avoid or rationalize, past decisions, they will take into account everything to be found in those decisions. Principles not fully articulated by the author of a prior opinion can be gleaned from explanatory remarks and cases cited by the author as similar or distinct. Stated rules or principles can be expanded to include a case that is not covered by their terms, and explanatory remarks, citations, and trends of decision over time may suggest an analogy-warranting rule that will serve this purpose. Neither of these strategies is strictly deductive-the present judge contributes to the new principle or rule and reviews its moral plausibility ${ }^{61}$ And neither limits the source of analogy to facts and results of prior cases. At the same time, both strategies perform the epistemic and institutional functions I have attributed to analogical reasoning. They engage judges in the study of prior cases, capture the insights of other judges, track the features of prior decisions on which actors might rely, and hold judges to modest revisions or expansions of existing law.

In addition, prior cases need not be treated equally as sources for analogy. A group of closely related cases that build on one another is a good source from which to draw an analogywarranting rule or principle. When there are only a few cases, with no express relation among them, the principle is speculative at best. Old cases or idiosyncratic cases, seldom cited, can be passed by without much loss of epistemic value. Discriminations of this sort add an element of discretion to analogical reasoning, but the important part of the practice remains: the sense of obligation to study prior cases and either conform to them or explain why they should be disregarded.

\section{CONCLUSION}

I have suggested that the practice of analogical reasoning from prior decisions has advantages, both epistemic and institutional, that exceed its rational force. The arguments I have made are quite traditional, yet they have not been prominent in other

\footnotetext{
${ }^{60}$ Dworkin, Law's Empire at 239-40, 284-85 (cited in note 1) (stating that "fit" with past judicial rhetoric is only "one desideratum").

${ }^{61}$ See Schauer, Playing by the Rules at 183-87 (cited in note 23).
} 
recent defenses of analogical reasoning. ${ }^{62}$ Perhaps this is because they admit that the outcome of analogical reasoning may be flawed and accept that the method of analogy may limit the ability of judges to bring about legal and social reform.

In my view, however, these are not fatal objections. Law is not an enterprise that admits of perfection. The most obvious reason for this is that law must rely on general rules, which inevitably will dictate the wrong result in some of the cases that fall within their terms. General rules are nevertheless justified if they prevent more errors than they bring about. ${ }^{63}$

If I am right about the benefits of the practice of analogical reasoning, then this practice can function in much the same way as a good rule. By displacing open-ended reasoning, it can correct errors and keep law on a stable path. Of course a practice such as analogical reasoning is quite different from a rule: just how judges are to draw comparisons among cases is not something that can be captured in canonical form. Nevertheless, a practice of analogical reasoning, ingrained by training and tradition, can work indirectly-in the manner of a rule-to improve the quality of judicial decisionmaking.

It may seem a shame to anchor the decisions of an exceptionally wise and intelligent judge to a seriously flawed line of past decisions when important matters are at stake. It may also be discouraging to think that one's favorite judicial innovation might have been passed over by a judge who felt bound to proceed by the inhibiting method of analogy. But most judges are not exceptional, and most cases do not raise defining questions of social character. The method in which judges are trained and habituated should be the one that will serve best in the mass of ordinary decisions by ordinary judges. In any event, a practice such as analogical reasoning may have little effect in extraordinary circumstances. Because it is simply a practice, with nothing standing behind it but habit, general acceptance, and the sense that it has worked well over time, it will sometimes be trumped by glaring error or urgent need.

\footnotetext{
a2 Sunstein makes brief reference to modesty and to concern for reliance, but distances himself from conservative arguments on behalf of analogical decisionmaking. Sunstein, Political Conflict at 76, 94-96 (cited in note 1).

* See note 39.
} 


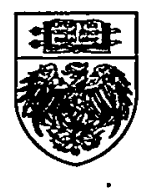

